\title{
THE INVERTEBRATE COLONIZATION DURING DECOMPOSITION OF Eichhornia azurea KUNTH IN A LATERAL LAKE IN THE MOUTH ZONE OF PARANAPANEMA RIVER INTO JURUMIRIM RESERVOIR (SÃO PAULO, BRAZIL)
}

\author{
STRIPARI, N. de L. and HENRY, R. \\ Departamento de Zoologia, Instituto de Biociências, Unesp, C.P. 510, CEP 18618-000, Botucatu, São Paulo, Brazil \\ Correspondence to: Raoul Henry, Departamento de Zoologia, Instituto de Biociências, Unesp, C.P. 510, \\ CEP 18618-000, Botucatu, São Paulo, Brazil, e-mail: rhenry@ibb.unesp.br \\ Received April 12, 2001 - Accepted August 6, 2001 - Distributed May 31, 2002
}

(With 17 figures)

\begin{abstract}
The invertebrate colonization during decomposition of Eichhornia azurea was observed in a lateral lake in the mouth zone of Paranapanema River into Jurumirim Reservoir in two periods of the year. The litter bags method was used for measuring the decomposition rate as well as to evaluate the invertebrates colonization. Forty-two litter bags, measuring $15 \times 20 \mathrm{~cm}$ in size and $2 \mathrm{~mm}$ mesh net, were incubated "in situ". Six litter bags (three for colonization and three for decomposition measurements) were removed after the $1^{\text {st }}, 3^{\text {rd }}, 7^{\text {th }}, 14^{\text {th }}, 28^{\text {th }}, 56^{\text {th }}$ and $72^{\text {nd }}$ days of incubation. After each day, the material was carefully cleaned for detritus removal and invertebrate sampling. The biological material was fixed with $4 \%$ formaline and then sorted and identified. The remaining plant material was dried in an oven $\left(\right.$ at $60^{\circ} \mathrm{C}$ ) and weighed. A fast material loss occurred during the first 24 hours and the decomposition rate was higher during the rainy season than in the dry season. A peak on invertebrate density (110 ind.g.DW $\left.{ }^{-1}\right)$ on the remaining detritus of Eichhornia azurea was recorded in the $56^{\text {th }}$ day of dry season, when the polyphenol concentration of plant detritus was $0.57 \mathrm{UDO} . \mathrm{g} . \mathrm{DW}^{-1}$. In the rainy season, higher density was found in the $28^{\text {th }}$ day of incubation, when the polyphenol concentration was 4.36 UDO.g.DW ${ }^{-1}$. Apparently, the reduction in the polyphenol concentration was followed by an increase in invertebrate densities. The majority of the species observed in the detritus belongs to the collector group that was dominant after the $7^{\text {th }}$ and $14^{\text {th }}$ days in the rainy and dry seasons, respectively.
\end{abstract}

Key words: decomposition, colonization, invertebrate, Eichhornia azurea, lake.

\section{RESUMO}

\section{Decomposição de Eichhornia azurea e colonização por invertebrados}

A colonização por invertebrados durante o processo de decomposição de Eichhornia azurea foi examinada em duas épocas do ano na zona de desembocadura do Rio Paranapanema, na Represa de Jurumirim, em lagoa lateral. O método utilizado para avaliar a taxa de decomposição bem como a colonização concomitante pelos invertebrados foi o uso dos litter bags em número de 42 com tamanho $15 \times 20 \mathrm{~cm}$ e $2 \mathrm{~mm}$ de abertura de malha. Seis litter bags (três para determinação da taxa de decomposição e três para estimativa de densidade de organismos) foram removidos por sorteio no $1^{\circ} \stackrel{\circ}{3} 3^{\circ}$, $7^{\circ}$, $14^{\circ}$, $28^{\circ}$, $56^{\circ}$ e $72^{\circ}$ dias de incubação. Após cada período de incubação, o material foi cuidadosamente lavado para facilitar a separação dos detritos e invertebrados. Em seguida, o material biológico foi fixado com formol $4 \%$ e posteriormente triado e identificado sob microscópio estereoscópico. O material vegetal remanescente foi seco a $60^{\circ} \mathrm{C}$ e pesado. Ocorreu rápida perda de material nas primeiras 24 horas e a taxa de decomposição de Eichhornia azurea foi maior no período chuvoso, em relação à estação seca. A maior densidade de invertebrados nos detritos de Eichhornia azurea foi observada 
na estação seca no 56º dia de incubação com aproximadamente 110 ind.g. PS $^{-1}$ quando os detritos da planta apresentavam um teor de 0,57 UDO.g.PS ${ }^{-1}$ de polifenóis. No período chuvoso, a maior densidade foi encontrada no $28^{\circ}$ dia de incubação quando o teor de polifenóis era de 4,36 UDO.g.PS ${ }^{-1}$. Observouse que a redução dos teores de polifenóis tem efeito aparente sobre o aumento da densidade de invertebrados. A maioria das espécies encontradas pertence ao grupo dos coletores, que foi dominante no período chuvoso (a partir do 7º dia) e seco (a partir do $14^{\circ} \stackrel{\text { dia}}{ }$ ).

Palavras-chave: decomposição, colonização, invertebrados, Eichhornia azurea, lagoa.

\section{INTRODUCTION}

Studies on invertebrates living in macrophyte stands have shown a great species richness and a high density of organisms when compared with the benthic fauna in sediments (Soszka, 1975; Ramcharan \& Paterson, 1978). Vicent et al. (1982) observed that the fauna in the macrophytes presents a magnitude of two to three times the abundance of zoobenthos in the litoral zone.

Macrophytes are an important biotope for the aquatic invertebrates. A significant number of organisms use this habitat for reproduction, for protection against predators and for food resources, during part or all their life cycle. According to Gadelha et al. (1990), the aquatic macrophytes present high nutritive quality and are an important food resource for aquatic animals. However, in some ecosystems, they are a very significant source of organic matter for the detritivorous chain, specially in tropical regions where the high temperatures increase the decomposition velocity of particulate matter (Junk et al., 1989).

The degradation of organic matter is the main recycling process of the majority of the nutrients stocked in the biomass of aquatic macrophytes. Thus, decomposition rate measurement of aquatic macrophyte biomass is decisive in tropical regions for the knowledge of the different steps of the aquatic metabolism, as well as of primary productivity and flux of energy into the different trophic levels. Roland et al. (1990) observed that during the first days of decomposition of Eichhornia azurea there is a high loss of polyphenols from the detritus. The polyphenol reduction causes an increase in the palability of the remaining organic matter for the members of the detritivorous chain. Pagioro \& Thomaz (1998), in laboratory studies, showed that the decomposition rates of Eichhornia azurea from Paraná River and Garças Lake (a lateral lake) are very similar and low. However, in another investigation, Pagioro \& Thomaz (1999) found that the decomposition rates of Eichhornia azurea, from Cortado channel and Guaraná Lake, in the floodplain of High Paraná River, were very different, despite the fact that the changes in ash and phosphorus contents were similar in both environments.

The purpose of this work was: a) to show the qualitative and quantitative differences in colonization by invertebrates during the Eichhornia azurea decomposition; b) to examine the influence of chemical composition, including the polyphenols, proteins, total nitrogen and phosphorus, in the remaining organic detritus on the invertebrate colonization during the macrophyte degradation; and c) to speculate on the role of the physical and chemical factors in the water, as controlling agents for the colonization and decomposition processes.

\section{MATERIAL AND METHODS}

\section{The study area}

This study was carried out in a lateral lake (Camargo Lake) of the Paranapanema River near the confluence with Guareí River, in its mouth zone into Jurumirim Reservoir (São Paulo, Brazil) (Fig. 1). In this area, an invasor gramineous (Echinochloa polystachya) is very abundant in all the litoral zone of Paranapanema River and in the internal right border of Camargo Lake (Pompêo, 1996). Stands of Eichhornia azurea present a patch distribution in some areas of both edges of the lake. According to Moschini-Carlos et al. (1998), a high connectivity is observed when the water level of Paranapanema River increases after the rainfall. The variability pattern during the year revealed a homogeneous vertical profile of almost all the abiotic factors, except for water temperature, $\mathrm{O}_{2}$ saturation and suspended matter that presented significant differences between the surface and the middle of water column (Moschini-Carlos et al., 1998). 


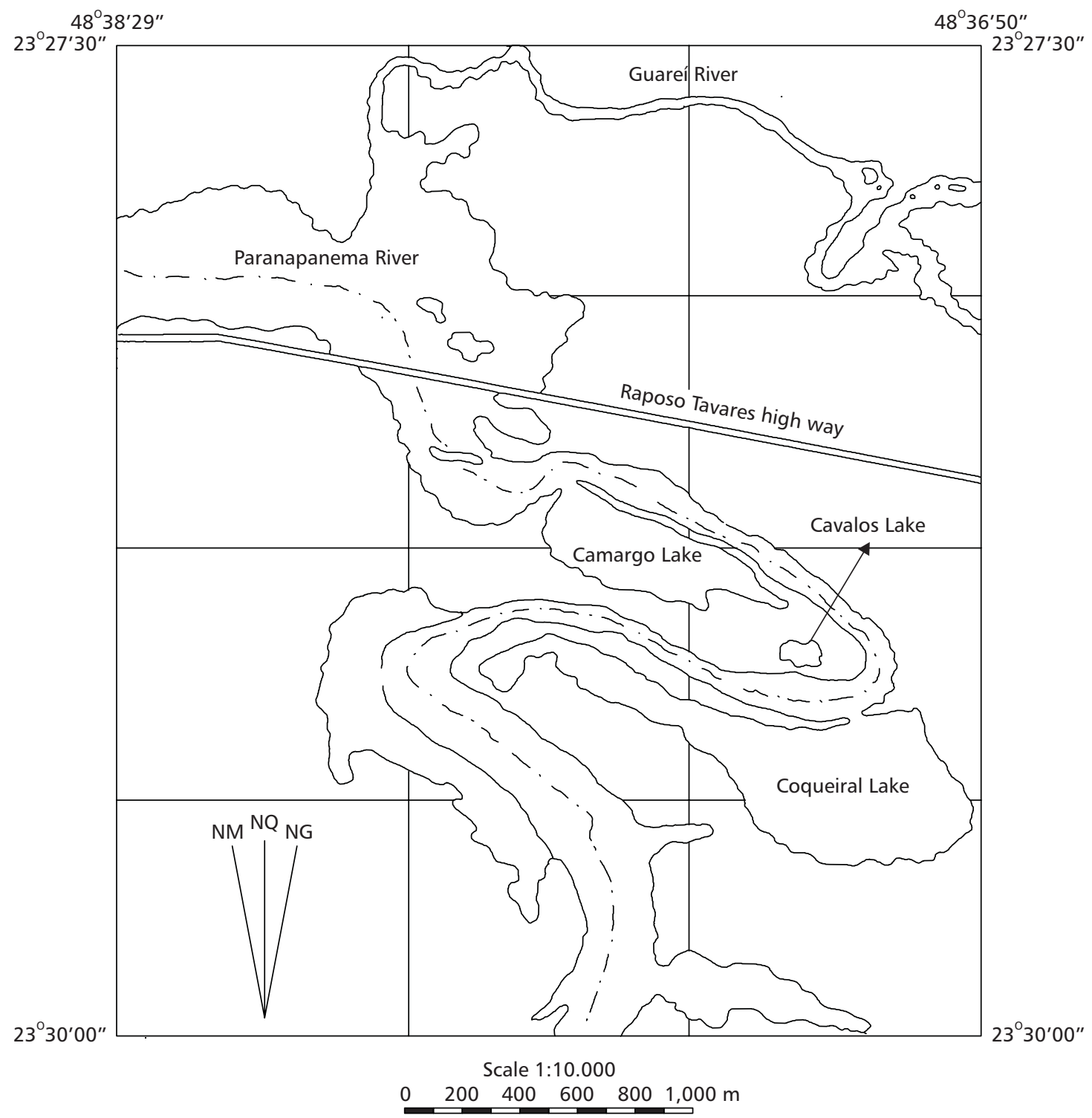

Fig. 1 - The study area: The Camargo Lake, a lateral lake in the mouth zone of the Paranapanema River into the Jurumirim Reservoir (São Paulo, Brazil).

\section{The experiments}

For the evaluation of the decomposition rate of Eichhornia azurea and the invertebrate colonization, the litter bags method was used in two experiments, one during the dry season (from August 4 to October 10, 1997) and the other in the rainy period (from January 12 to March 9, 1998). In each experiment, 42 litter bags ( 21 for the decomposition and 21 for the colonization experiments), mea- suring $15 \times 20 \mathrm{~cm}$ in size and $2 \mathrm{~mm}$ mesh net, were incubated "in situ" near a Eichhornia azurea stand. In each litter bag, 15 g.DW of the plant (leaf and petiole) were added. After 1, 3, 7, 14, 28, 56 and 72 days of incubation, 6 litter bags (three for the decomposition and the others for colonization measurements) were drawn and then removed in each period. The remaining material was cleaned in a $0.25 \mathrm{~mm}$ mesh sieve for invertebrate sorting. 
The biological material was fixed in $4 \%$ formaline, then sorted and identified according to relevant specialized literature (Reid, 1982; MatsumuraTundisi, 1986; Epler, 1992; Assis \& Costa, 1994; Lopretto \& Tell, 1995; Trivinho-Strixino \& Strixino, 1995; Merrit \& Cummins, 1996; Elmoor-Loureiro, 1997) and the density (ind.g.DW ${ }^{-1}$ ) calculated. The trophic level of the functional groups of invertebrates living in Eichhornia azurea was determined according to information in Pennak (1991) and Merrit \& Cummins (1996). The remaining material was dried in an oven $\left(60^{\circ} \mathrm{C}\right)$. The decomposition rate $(\mathrm{k})$ was determined through the equation $\mathrm{B}_{1}=$ $\mathrm{B}_{\mathrm{o}} \cdot \mathrm{e}^{-\mathrm{kt}}$, where $\mathrm{B}_{\mathrm{o}}$ and $\mathrm{B}_{1}$ are biomass in the times $\mathrm{t}_{\mathrm{o}}=0$ and $\mathrm{t}_{1}=1,3,7,14, \ldots, 72$ days and $\mathrm{t}=$ time interval (in days between $\mathrm{B}_{0}$ and $\mathrm{B}_{1}$ ). The period for decomposition of $50 \%$ and $95 \%$ of the initial biomass (15 g) was estimated. The remaining dry material was ground for total phosphorus (Anderson, 1976), total nitrogen (by Kjedahl method using Bucchi equipment) and polyphenol analysis (King \& Heath, 1967). The protein concentration was found through the product of total $\mathrm{N}$ by 6.25 (Boyd,
1970). The ash content was determined by the burning of a sample (0.3 g.DW) in a furnace (at $550^{\circ} \mathrm{C}$, for 4 hours). The organic matter amount is the difference between detritus dry weight and ash content and carbon corresponds to $47 \%$ of organic matter.

Water transparency (by Secchi disk) and temperature (by Toho Dentam thermistor) were measured in Camargo Lake. Water was also sampled for $\mathrm{pH}$ determination (by $\mathrm{pHmeter} \mathrm{Micronal} \mathrm{Mod.}$ B180), conductivity (at $25^{\circ} \mathrm{C}$, by a conductivimeter Hatch Mod.2511), alkalinity and dissolved oxygen (Golterman et al., 1978), suspended matter (by gravimetry), total $\mathrm{N}$ (by Kjedahl method using Bucchi equipment) and phosphorus (Golterman et al., 1978).

\section{RESULTS}

Water temperature in the surface of Camargo Lake ranged from 16.1 to $24.5^{\circ} \mathrm{C}$ in the dry season and from 19.8 to $32.0^{\circ} \mathrm{C}$ in the rainy season (Table 1).

TABLE 1

Water temperature and transparency in Camargo Lake (lateral to Paranapanema River) during the experiment in the dry (first day: 97/8/4) and rainy (first day: 98/1/12) periods.

\begin{tabular}{|c|c|c|c|c|c|c|}
\hline \multirow{2}{*}{$\begin{array}{c}\text { Days of the } \\
\text { experiment }\end{array}$} & \multicolumn{3}{|c|}{ Dry period } & \multicolumn{3}{c|}{ Rainy period } \\
\cline { 2 - 7 } & $\begin{array}{c}\text { Hour of } \\
\text { sampling }\end{array}$ & $\begin{array}{c}\text { Temperature } \\
\left({ }^{\mathbf{C}} \mathbf{C}\right)\end{array}$ & $\begin{array}{c}\text { Transparency } \\
(\mathbf{m})\end{array}$ & $\begin{array}{c}\text { Hour of } \\
\text { sampling }\end{array}$ & $\begin{array}{c}\text { Temperature } \\
\left({ }^{\mathbf{C}} \mathbf{C}\right)\end{array}$ & $\begin{array}{c}\text { Transparency } \\
(\mathbf{m})\end{array}$ \\
\hline $\mathbf{0}$ & $9: 25$ & 17.8 & 1.23 & $9: 55$ & 25.4 & 0.49 \\
\hline $\mathbf{1}$ & $8: 50$ & 17.5 & 1.19 & $8: 40$ & 25.9 & 0.46 \\
\hline $\mathbf{3}$ & $9: 28$ & 18.0 & 0.98 & $8: 45$ & 26.1 & 0.35 \\
\hline $\mathbf{7}$ & $9: 50$ & 16.1 & 0.80 & $9: 23$ & 27.4 & 0.38 \\
\hline $\mathbf{1 4}$ & $9: 30$ & 18.4 & 1.22 & $9: 25$ & 28.0 & 0.68 \\
\hline $\mathbf{2 8}$ & $9: 30$ & 20.3 & 0.83 & $10: 30$ & 32.0 & 0.89 \\
\hline $\mathbf{5 6}$ & $9: 35$ & 20.6 & 0.60 & $10: 45$ & 27.4 & 0.17 \\
\hline $\mathbf{7 2}$ & $10: 20$ & 24.5 & 0.52 & $9: 55$ & 19.8 & 0.57 \\
\hline
\end{tabular}

In August, 1997 high water transparency was observed and the lowest Secchi disk transparency was found in the rainy period (at the $56^{\text {th }}$ day of incubation). The highest dissolved oxygen concentrations were obtained after 7 and 14 days of incubation ( 8.93 to $8.62 \mathrm{mg} . \mathrm{L}^{-1}$, respectively) in the dry period and the lowest value $\left(4.14 \mathrm{mg} . \mathrm{L}^{-1}\right)$ was recorded in the rainy season after 72 days of incubation (Fig. 2a). The highest alkalinity value was found in the rainy season $\left(0.492\right.$ meq. $\left.\mathrm{L}^{-1}\right)$ and the lowest in the dry season $\left(0.387\right.$ meq. $\left.\mathrm{L}^{-1}\right)$ (Fig. 2b). Values for $\mathrm{pH}$ ranged from 5.9 to 6.5 
in the dry period and from 6.1 to 7.3 in the rainy season (Fig. 2c). The highest and lowest conductivity values were $77 \mu \mathrm{S} . \mathrm{cm}^{-1}$ (dry season) and $36 \mu \mathrm{S} . \mathrm{cm}^{-}$ ${ }^{1}$ (rainy season) (Fig. 2d). The highest amount of suspended matter was found in the $3^{\text {rd }}$ day in the dry period $\left(70.1 \mathrm{mg} . \mathrm{L}^{-1}\right)$ and the lowest in the $72^{\text {nd }}$ day in the rainy season (Fig. 2e). High concentrations of total nitrogen were recorded during the first three days of the experiment in January, 1998 (Fig. 3). In the $7^{\text {th }}$ day, a significant decrease was observed, followed by an increase in total N. In the dry period (August, 1997), the lowest values were obtained after 3 and 7 days of incubation. The total $\mathrm{P}$ in lake water ranged from 13 to 41

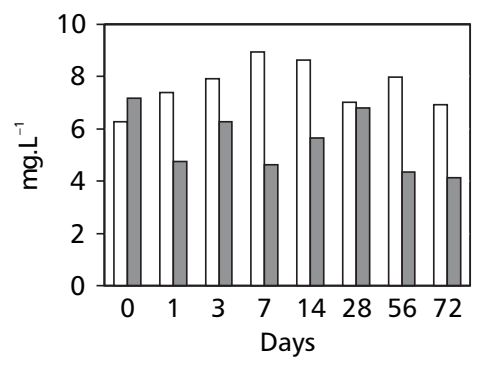

a)

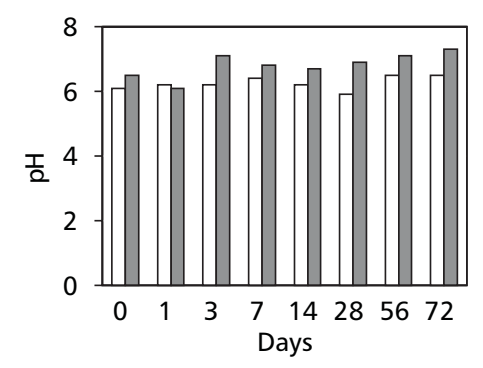

c) $\mu \mathrm{g} . \mathrm{L}^{-1}$ (dry period) and from 30 to $48 \mu \mathrm{g} . \mathrm{L}^{-1}$ (rainy season) (Fig. 4).

In both periods, a fast loss of initial biomass of Eichhornia azurea was observed in the first 24 hours (Figs. 5 and 6). Higher decomposition rate was found in the rainy season $(\mathrm{k}=0.0175)$ when compared with the dry period $(\mathrm{k}=0.0135)$, but no significant difference $(\mathrm{p}<0.05)$ was recorded. The time necessary for the degradation of $50 \%$ of initial biomass was estimated in 51 and 40 days, for the dry and rainy seasons respectively. For the decomposition of $95 \%$ of biomass, the time would be 221 and 171 days, for the dry and rainy periods respectively.

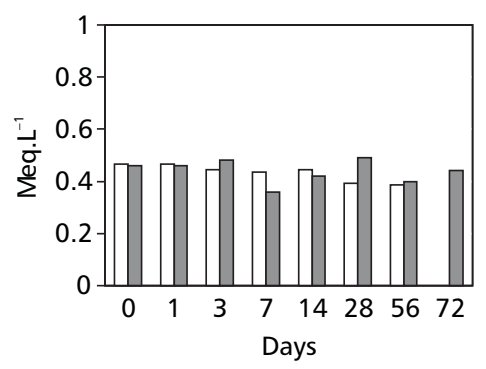

b)

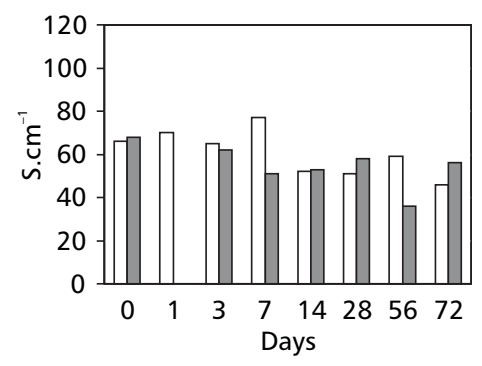

d)

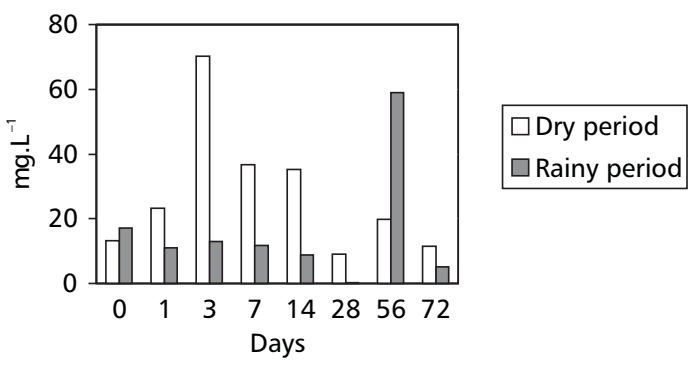

e)

Fig. 2 - Dissolved oxygen (a), alkalinity (b), pH (c), conductivity (d) and suspended matter (e) variations in Camargo Lake during the colonization and decomposition experiments at dry and rainy periods. 


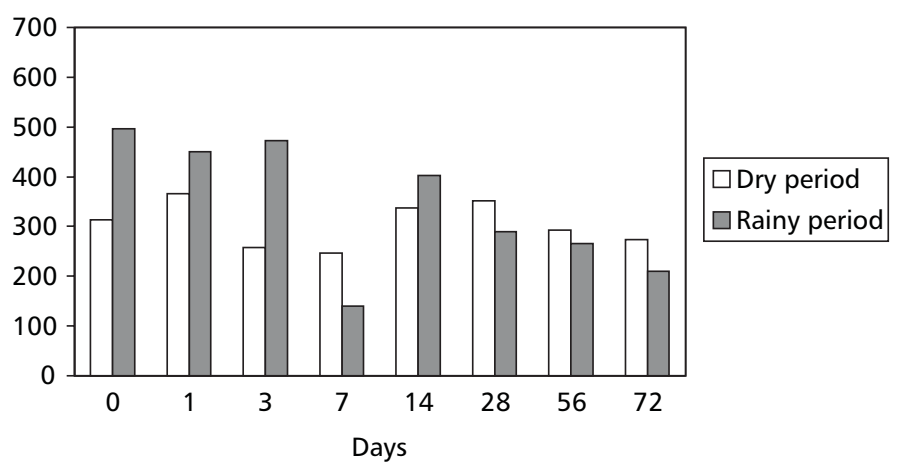

Fig. 3 - Total nitrogen $\left(\mu \mathrm{g} . \mathrm{L}^{-1}\right)$ variations in water of Eichhornia azurea stand in Camargo Lake during the colonization and decomposition experiments at the dry and rainy periods.

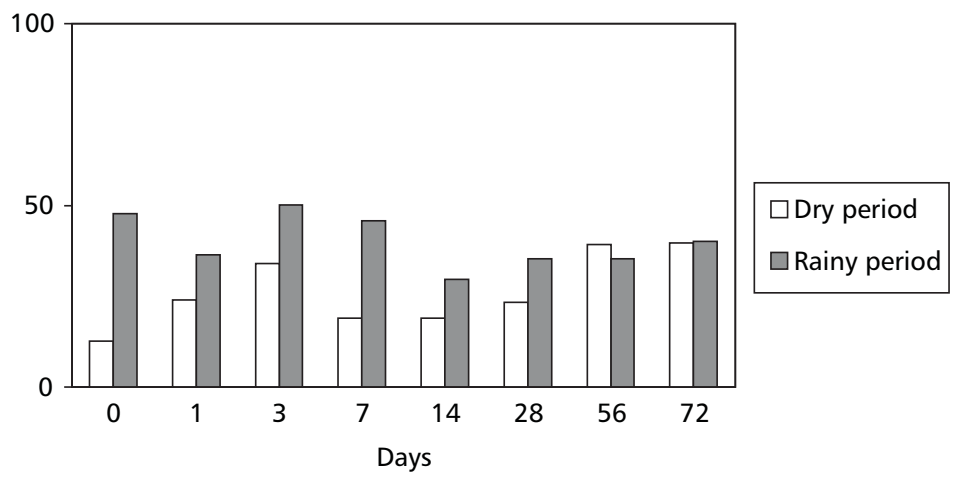

Fig. 4 - Total phosphorus ( $\left.\mu \mathrm{g} . \mathrm{L}^{-1}\right)$ variations in water of Eichhornia azurea stand in Camargo Lake during the colonization and decomposition experiments at the dry and rainy periods.

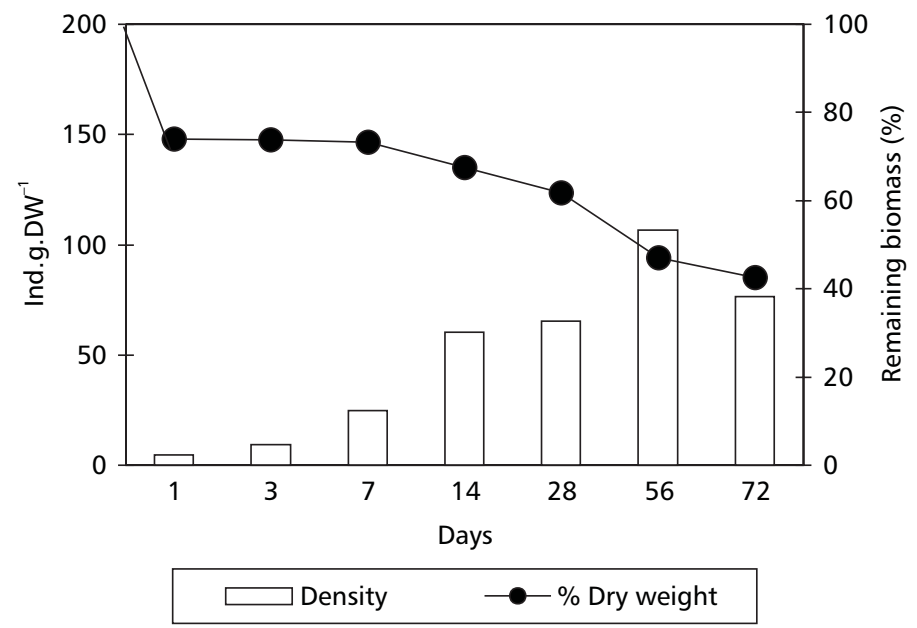

Fig. 5 - Total invertebrate density (Ind.g.DW ${ }^{-1}$ ) in Eichhornia azurea, during the decomposition experiment at Camargo Lake in the dry period. 


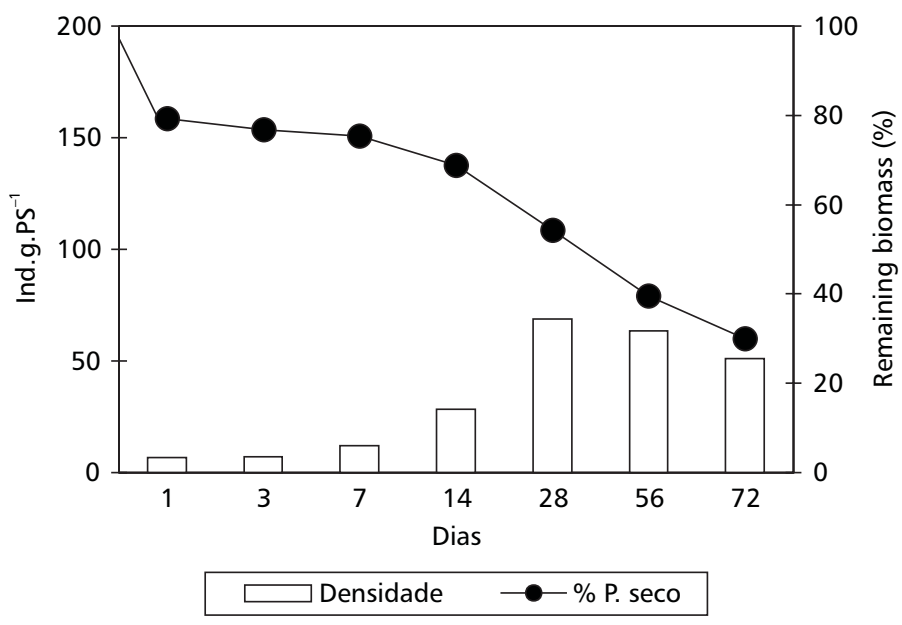

Fig. 6 - Total invertebrate density (Ind.g.DW $\left.{ }^{-1}\right)$ in Eichhornia azurea, during the decomposition experiment at Camargo Lake in the rainy period.

Total phosphorus percentages in the remaining biomass of Eichhornia azurea were higher during the dry period (Fig. 7). In both seasons, a decrease in percentages was observed up to the $28^{\text {th }}$ day, followed by an increase that was lower than in the first day (Fig. 7). In relation to remaining total nitrogen, a small increase in values was observed in the $3^{\text {rd }}$ day of both periods; a reduction was found in the $7^{\text {th }}$ day, and from the $14^{\text {th }}$ day on there was an increase of nitrogen. The percentages were high and presented no significant changes up to the $72^{\text {nd }}$ day (Fig. 8). During the decomposition of Eichhornia azurea, a decrease in polyphenol contents was observed in both seasons (Fig. 9). Concentrations decreased from 23.28 to 0.45 UDO.g.DW ${ }^{-1}$ in the dry period, while in the rainy season, from 32.85 to 0.47 UDO.g.DW ${ }^{-1}$. The highest ash amount was found in the $72^{\text {nd }}$ day $(12.54 \%)$ in the dry season and in the $56^{\text {th }}$ day $(7.83 \%)$ in the rainy season (Fig. 10). The lowest percentages (ca. 4\%) were recorded in the $1^{\text {st }}$ and $28^{\text {th }}$ days in the rainy period. In relation to organic matter, a low variation occurred during the first 28 days in the rainy season (Fig. 11). A reduction was observed in the $56^{\text {th }}$ day and an increase was recorded in the $72^{\text {nd }}$ day. However, a great variability on percentages of organic matter in remaining biomass occurred during the dry period (Fig. 11).
In the beginning of both experiments, the carbon percentages were similar, but, at the end ( $\left.72^{\text {nd }} d a y\right)$, the percentage in the remaining biomass was higher than in the rainy season (Fig. 12). The remaining protein was lower during the first 28 days in the rainy season (Fig. 13). In the other two dates, the percentages were similar in the rainy as well as in the dry periods.

A study on the relationship between the decomposition rate (k) of Eichhornia azurea and the physical and chemical factors of water in Camargo Lake and, with the compounds (total $\mathrm{N}$ and $\mathrm{P}$, polyphenol and organic matter) of plant detritus was made through a multiple correlation analysis (Sokal \& Rohlf, 1995). The fitted multiple correlations ( $\mathrm{R})$ between $\mathrm{k}$ and water abiotic factors were 0.994 and 0.998 for dry and rainy seasons respectively. In order to evaluate the relationship between each environmental factor and the detritus compounds with $\mathrm{k}$, a study on the correlation between the variables was made (Table 2). During the dry season, dissolved oxygen and total phosphorus in water presented negative correlations with $\mathrm{k}$, while with alkalinity, water transparency and total $\mathrm{P}$ in detritus, the correlations were positive. In the rainy period, only $\mathrm{pH}$ showed a negative correlation with $\mathrm{k}$, while with conductivity and total nitrogen in water, the correlations were positive. 


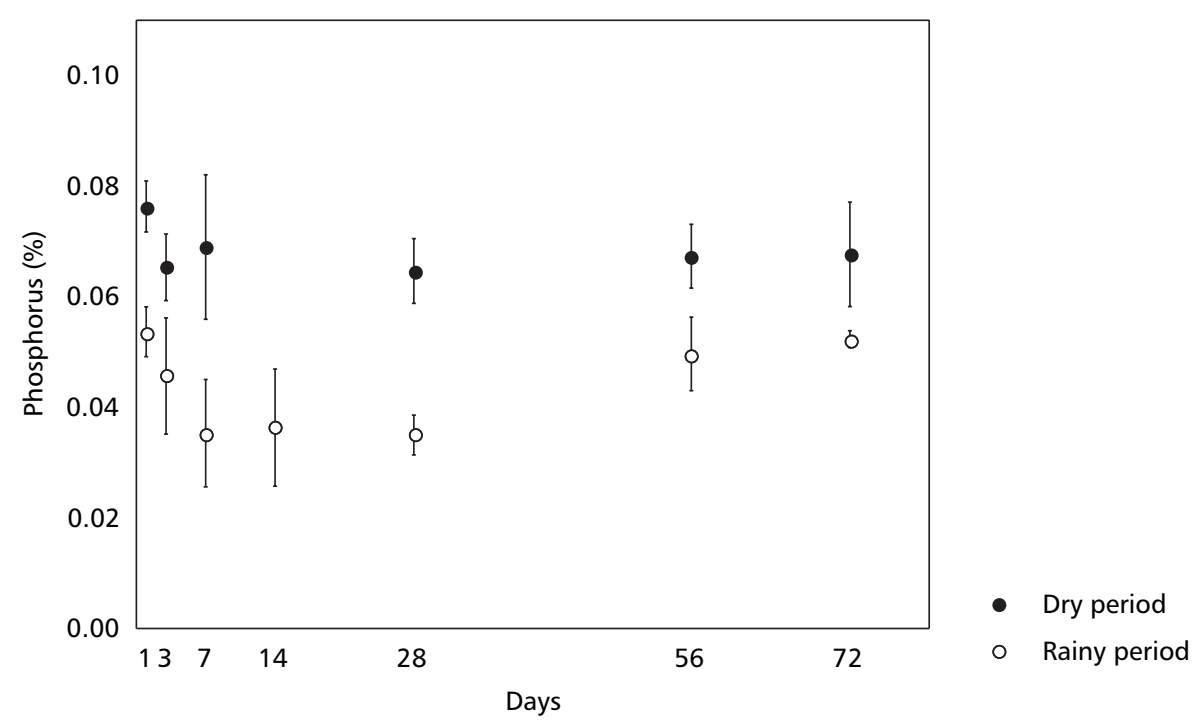

Fig. 7 - Mean \pm SD of total phosphorus in the remaining biomass of Eichhornia azurea.

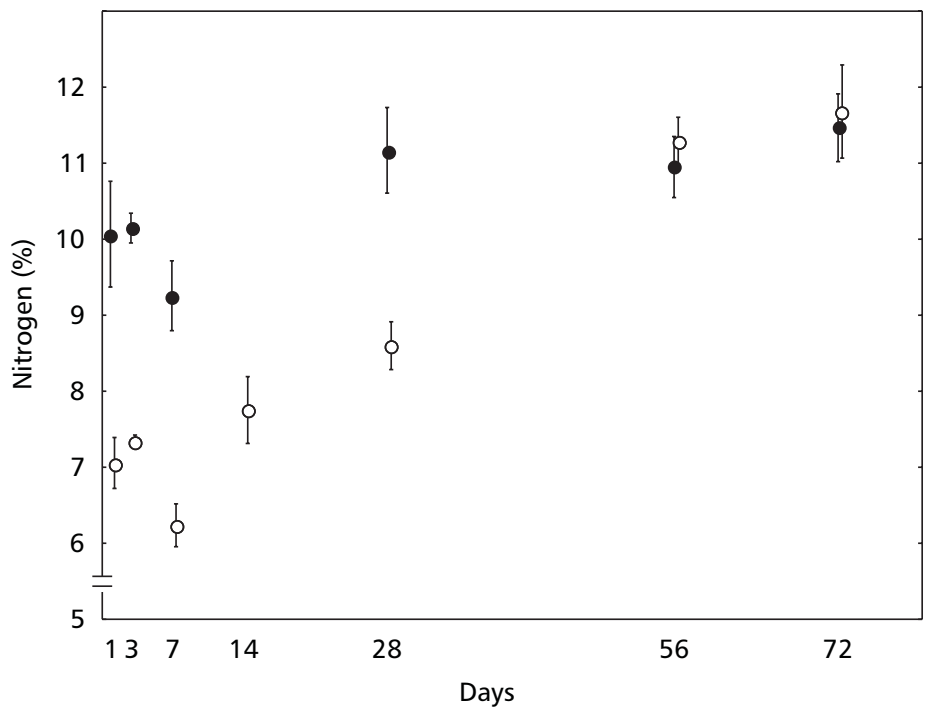

- Dry period

- Rainy period

Fig. 8 - Mean \pm SD of total nitrogen in the remaining biomass of Eichhornia azurea. 


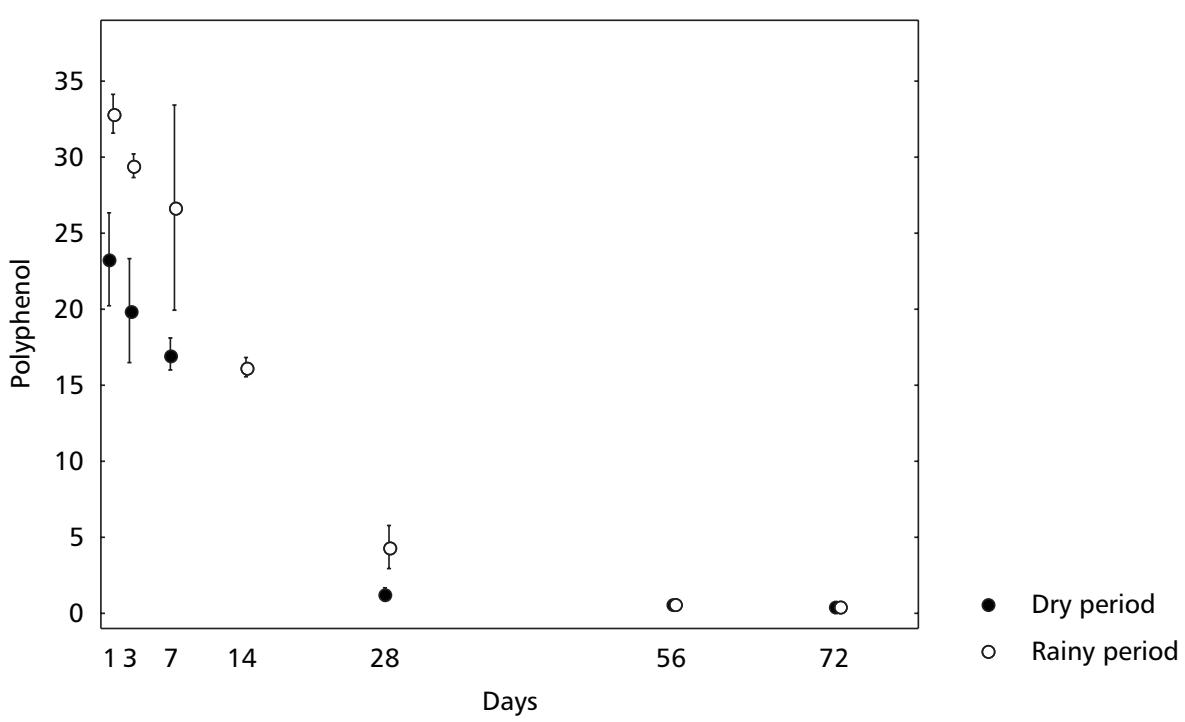

Fig. 9 - Mean \pm SD of polyphenols (UDO.g.DW ${ }^{-1}$ ) in the remaining biomass of Eichhornia azurea.

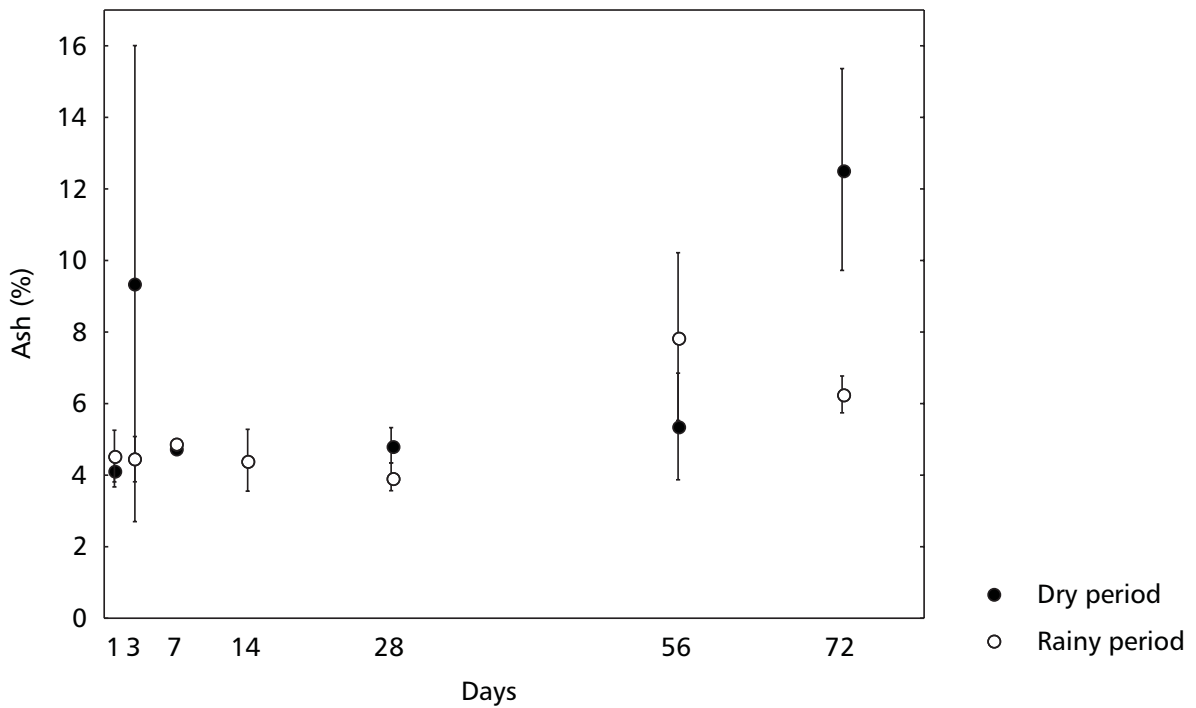

Fig. $10-$ Mean \pm SD of ash in the remaining biomass of Eichhornia azurea. 


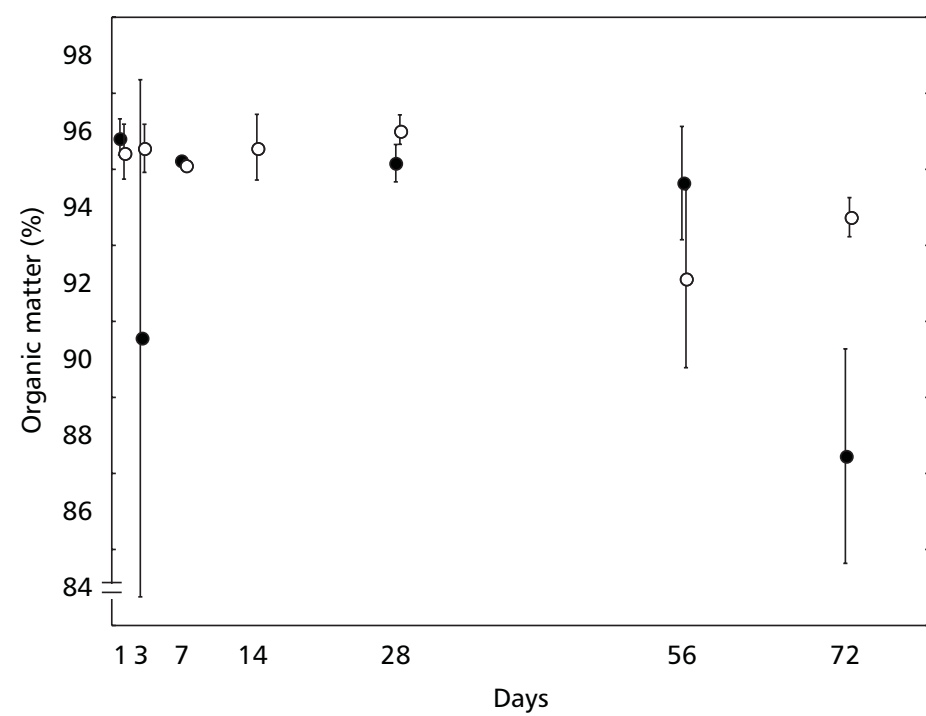

- Dry period

- Rainy period

Fig. 11 - Mean \pm SD of organic matter in the remaining biomass of Eichhornia azurea.

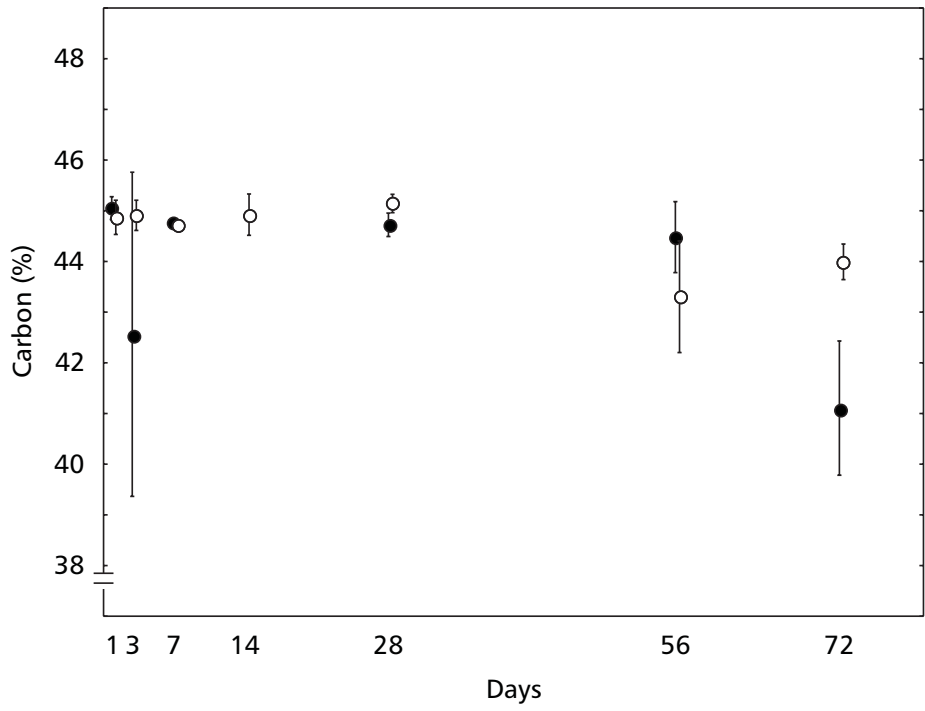

- Dry period

- Rainy period

Fig. 12 - Mean \pm SD of carbon in the remaining biomass of Eichhornia azurea. 


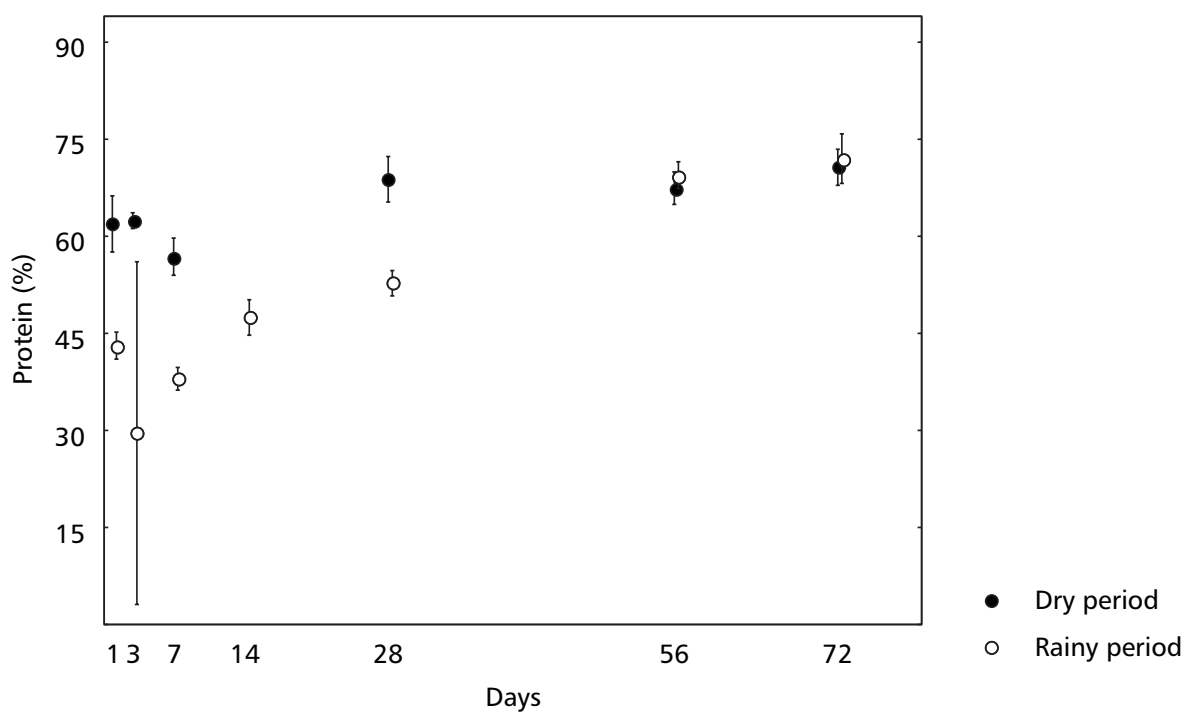

Fig. $13-$ Mean \pm SD of protein in the remaining biomass of Eichhornia azurea.

TABLE 2

Correlation coefficients (r) between decomposition rates (k) of Eichhornia azurea and water abiotic factors and compounds of detritus during the experiments (dry and rainy periods).

\begin{tabular}{|l|c|c|}
\hline \multicolumn{1}{|c|}{ Factors } & Dry period & Rainy period \\
\hline Temperature & -0.2755 & -0.1597 \\
\hline Dissolved oxygen & $-0.7645^{(1)}$ & 0.3514 \\
\hline Alalinity & $0.5598^{(1)}$ & 0.2591 \\
\hline $\mathrm{pH}$ & -0.2513 & $-0.7531^{(1)}$ \\
\hline Conductivity & 0.3591 & $0.6097^{(1)}$ \\
\hline Suspended matter & -0.3427 & -0.1302 \\
\hline Transparency & $0.5992^{(1)}$ & -0.0377 \\
\hline Total P in detritus & $0.5550^{(1)}$ & 0.4553 \\
\hline Total P in water & $-0.6141^{(1)}$ & 0.1800 \\
\hline Total N in detritus & -0.1998 & -0.1459 \\
\hline Total N in water & 0.3687 & $0.6362^{(1)}$ \\
\hline Polyphenols & 0.4953 & 0.4560 \\
\hline Organic matter & 0.3803 & 0.1920 \\
\hline
\end{tabular}

${ }^{(1)}$ Correlations with $\mathrm{r}$ values $>0.5$ were considered as significant for interpretation.

Despite the fact that Eichhornia azurea decomposition presents a high value of $\mathrm{k}$ in the rainy period, the invertebrate density during the degradation was lower than in the dry season (Figs. 5 and $6)$. The highest invertebrate density was found in the $56^{\text {th }}$ day of incubation in the dry period (Fig. 5).
In this time, Copepoda and Cladocera presented higher densities in the first days of incubation, being dominated by Mesocyclops longisetus and by Chydoridae, respectively. In a decreasing order of density, organisms of Chironomidae (with a predominance of Thienemanniella sp. and Crico- 
topus sp.) and of Oligochaeta were found (Fig. 14). In the rainy season, the abundance of Oligochaeta was high from the first to the $28^{\text {th }}$ day (Fig. 15). In the $56^{\text {th }}$ and $72^{\text {nd }}$ days, the relative density of Chironomidae increased due to the rise of Tibrelos sp.

From the first to the last days of colonization by invertebrates, all the functional feeding groups were observed in the remaining biomass of Eichhornia azurea during the two seasons (Figs. 16 and 17). In the dry period, the filter feeders and the collectors were the most important functional feeder groups (Fig. 16). In the $7^{\text {th }}$ day, the relative density of filter feeders corresponded to $40.9 \%$ of the total of organisms and, in the $56^{\text {th }}$ and $72^{\text {nd }}$ days, the collectors attained respectively $50.7 \%$ and $45.2 \%$ of the total abundance. In the dry period, the scrappers presented the highest density in the $3^{\text {rd }}$ day, while in the rainy season it occurred only in the $28^{\text {th }}$ day (Fig. 17). A great number of predators was recorded in the first day and from the $56^{\text {th }}$ day in the dry period (Fig. 16). In the rainy season, this functional feeding group showed only a relatively high density in the $72^{\text {nd }}$ day (Fig. 17). In both seasons, the shredders and the omnivorous presented low densities. The highest abundance of shredders (14\% of the total of organisms) was found in the $7^{\text {th }}$ day of the dry period (Fig. 16). Omnivorous had high importance only during the first three days in the two seasons. In the rainy period, the filter feeders corresponded to $60 \%$ of predominance of Thienemanniella sp. and Cricotopus sp.) and of Oligochaeta were found (Fig. 14). In the rainy season, the abundance of Oligochaeta was high from the first to the $28^{\text {th }}$ day (Fig. 15). In the $56^{\text {th }}$ and $72^{\text {nd }}$ days, the relative density of Chironomidae increased due to the rise of Tibrelos sp.

From the first to the last days of colonization by invertebrates, all the functional feeding groups were observed in the remaining biomass of Eichhornia azurea during the two seasons (Figs. 16 and 17). In the dry period, the filter feeders and the collectors were the most important functional feeder groups (Fig. 16). In the $7^{\text {th }}$ day, the relative density of filter feeders corresponded to $40.9 \%$ of the total density in the first day. In the remaining days, the dominance of collectors was evident.

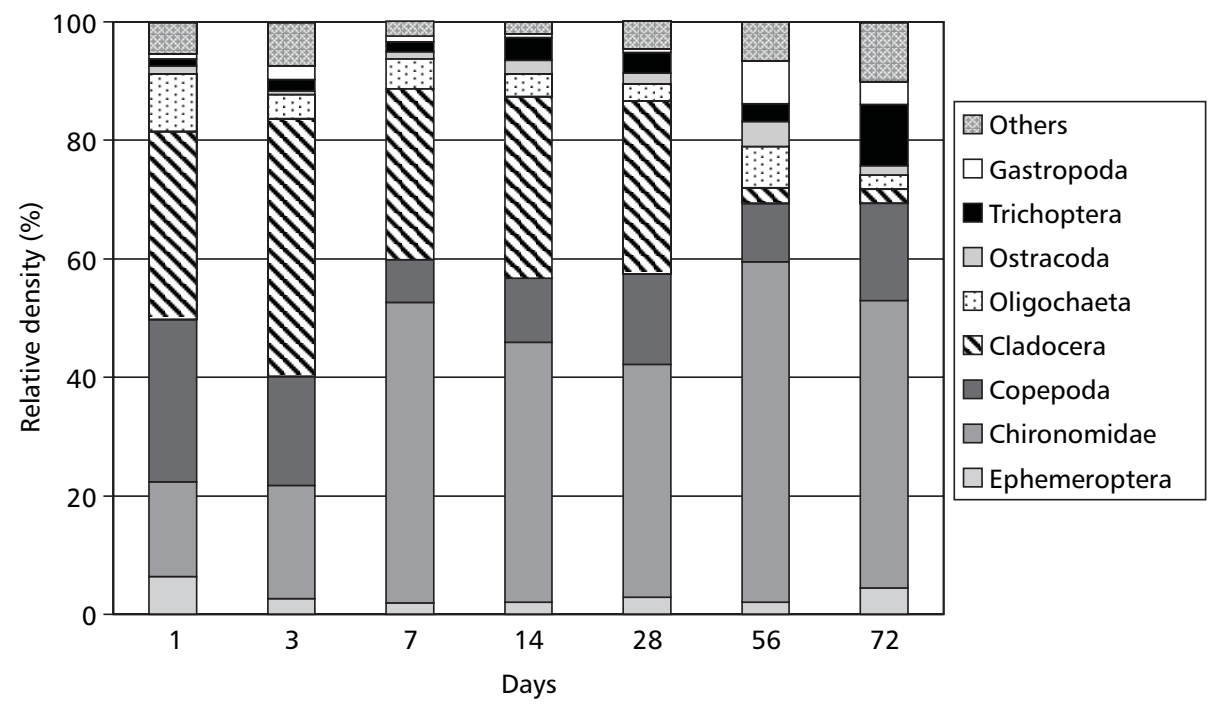

Fig. 14 - Relative density of invertebrates living on detritus of. E. azurea in the dry period (others = Coleoptera, Odonata, Hemiptera, Ceratopogonidae, Culicidae, Nematoda, Hirudinea, Hydracarina e Collembola). 


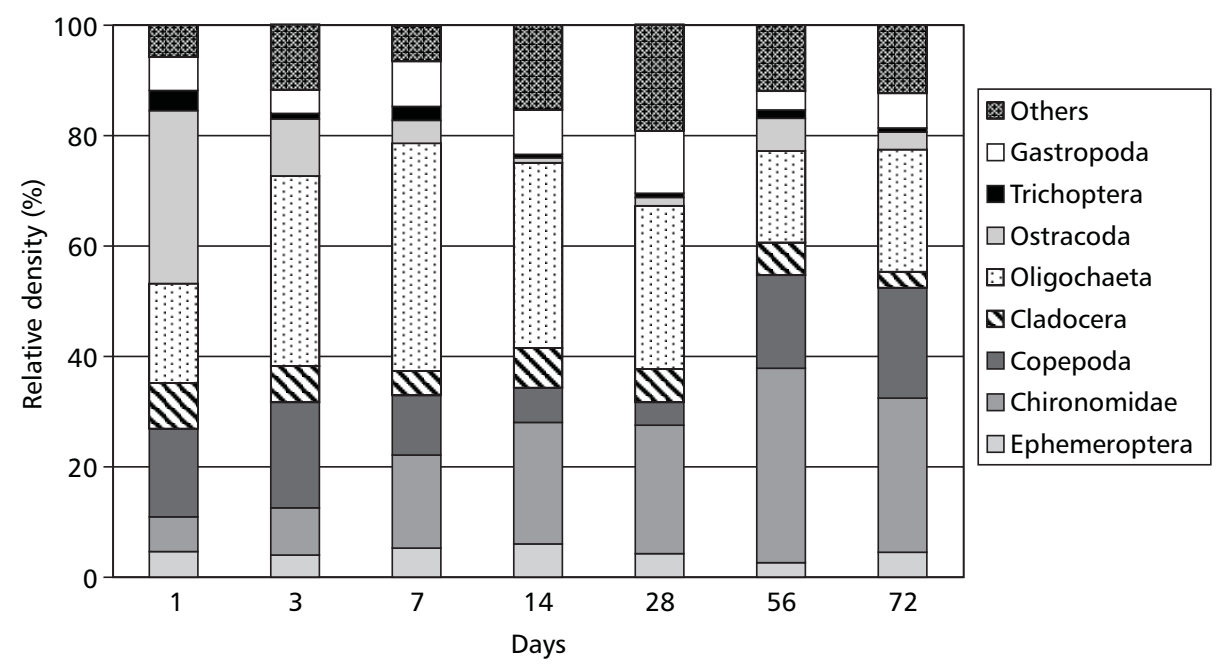

Fig. 15 - Relative density of invertebrates living on detritus of E. azurea in the rainy period (others = Coleoptera, Odonata, Hemiptera, Ceratopogonidae, Culicidae, Nematoda, Hirudinea, Hydracarina, Collembola e Bivalvia).

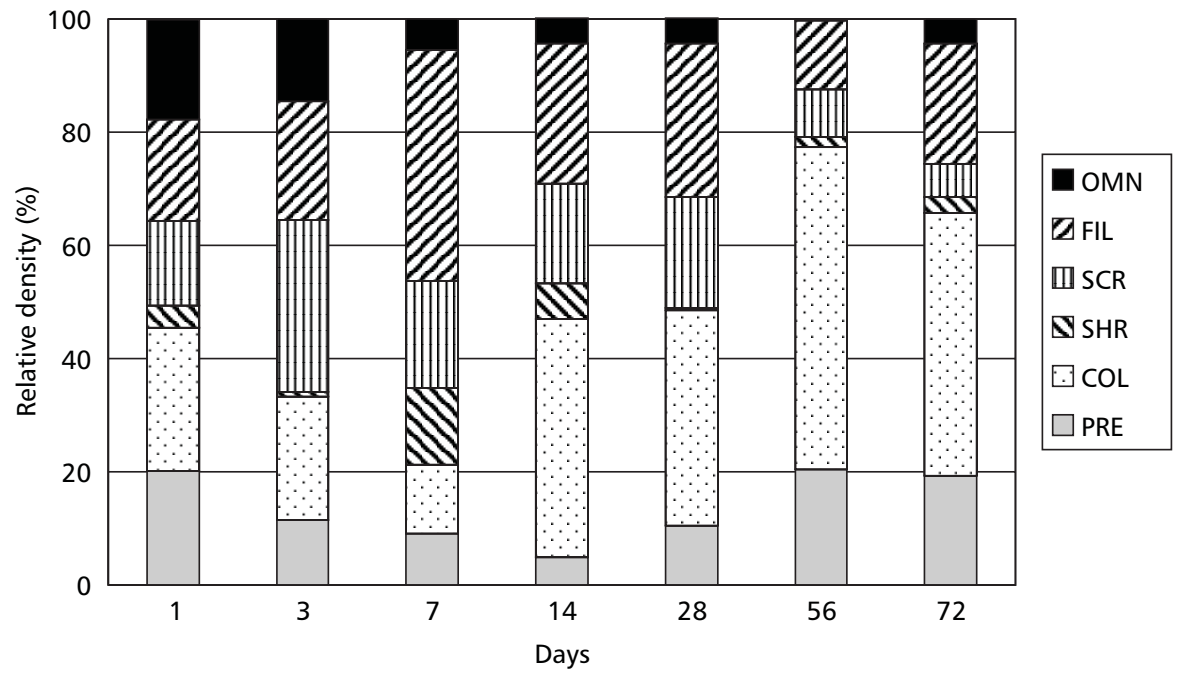

Fig. 16 - Relative density of functional feeding groups living on detritus of E. azurea during the dry period (ONI = omnivorous; $\mathrm{FIL}=$ filter feeders; $\mathrm{SCR}=$ scrappers $; \mathrm{SHR}=$ shredders $; \mathrm{COL}=$ collectors; $\mathrm{PRE}=$ predators $).$ 


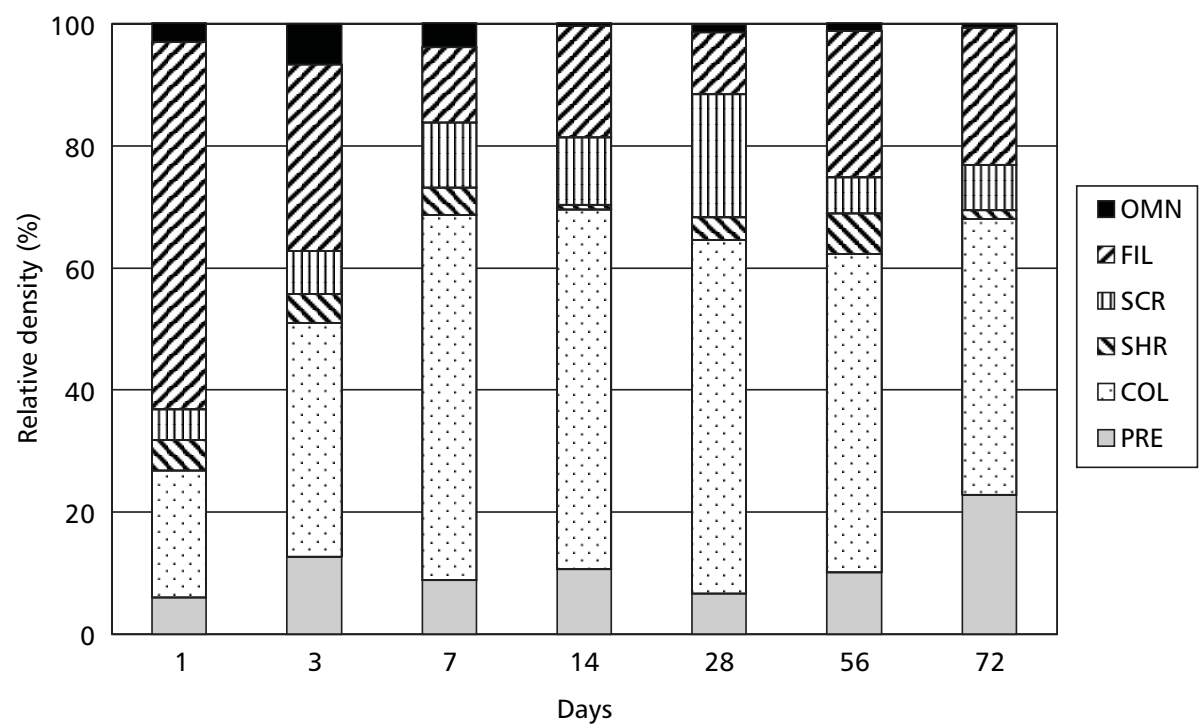

Fig. 17 - Relative density of functional feeding groups living on detritus of $E$. azurea during the rainy period (ONI = omnivorous; $\mathrm{FIL}=$ filter feeders; $\mathrm{SCR}=$ scrappers; $\mathrm{SHR}=$ shredders; $\mathrm{COL}=$ collectors; $\mathrm{PRE}=$ predators $).$

In order to show the influence of water abiotic factors and chemical compounds of detritus on densities of invertebrates living in the remaining biomass of Eichhornia azurea in both periods, a canonical correlation was used (Manly, 1994). The fitted correlations between the pairs of canonical variables (V1 and W1) were 0.09998 and 0.09981 for the dry and rainy seasons respectively, both significant considering $\mathrm{p}<0.05$. The canonical variable V1, that includes the densities of all the invertebrate groups on Eichhornia azurea during their degradation, presented a positive value (>0.5) for all the groups, except Cladocera in the dry period (Table 3 ). The canonical variable W1 that corresponds to water abiotic factors and chemical compounds of detritus, showed positive correlations $(>0.5)$ with temperature and total nitrogen in the remaining material and negative correlations with conductivity, water transparency and polyphenol. In the rainy season, V1 presented negative correlations (>0.5) with Chironomidae, Copepoda and Ostracoda (Table 3). The W1 variable showed positive correlations with temperature, transparency and polyphenol and negative with total $\mathrm{P}$ and $\mathrm{N}$ in the remaining material (Table 3).

\section{DISCUSSION}

According to Moschini-Carlos et al. (1998), the marginal bay of Paranapanema, also called Camargo Lake, receives riverine influences, specially when the hydrological level increases and a water input occurs into the lateral lake. The highest water level was observed in August during the dry season (Pompêo, 1996).

After the water input by the river, the suspended matter amounts were higher in the lake than in the rainy period (Fig. 2e). A dilution effect appears to occur since conductivity (Fig. 2d) and total phosphorus (Fig. 4) can be compared with the values of the rainy season. In this period, the water temperature was higher and the oxygen solubility reduced. As a result, oxygen concentrations were lower than in the dry period (Fig. $2 \mathrm{a}$ ). Both $\mathrm{pH}$ and alkalinity apparently presented no variations between the two seasons, and are not controlling factors of the water dynamics in the lateral lake.

The biomass decomposition is the main process for recycling the organic matter of aquatic macrophytes to mineral substances for the natural 
environment in a dissolved form. Two different phases took place during the decomposition process of Eichhornia azurea in Camargo Lake. In the first, a loss corresponding to $26 \%$ and $21 \%$ of biomass was observed during the first 24 hours in the dry and rainy periods respectively. In this phase, physical processes as cellular lysis and lixiviation occurred and a great quantity of organic and inorganic nutrients is removed from plants into the aqueous solutions. Pagioro \& Thomaz (1998), in a laboratory study on Eichhornia azurea decomposition sampled in two different ecosystems (Paraná River and Garças Lake) from the High Paraná River floodplain, found a loss of approximately $15 \%$ of leaf biomass during the first 24 hours, a slower decomposition therefore. In Camargo Lake, the second phase showed a very low velocity in decomposition, corresponding to $34 \%$ and $49 \%$ of initial biomass for 71 days in the dry and rainy periods, respectively. The decomposition of structural compounds as cellulose, hemicellulose and lignine by bacteria and fungus occur in this step of the process (Godshalk \& Wetzel, 1978). So, the decomposition rate is lower in this phase.

Eichhornia azurea decomposition rate (k) was expected to be higher in the rainy than in the dry period, when water temperature was above $25^{\circ} \mathrm{C}$. However, no significant difference between $\mathrm{k}$ values was found. According to Kaushik \& Hynes (1971), the velocity of detritus degradation depends on the chemical composition of plant, on the temperature and also on the amount of nutrients in water. In Camargo Lake, the decomposition rate $(\mathrm{k})$ presented a positive correlation with nitrogen in water and conductivity and, a negative correlation with $\mathrm{pH}$ during the rainy period. In the dry season, significant correlations were recorded with dissolved oxygen and total phosphorus in water (negative correlation) and with alkalinity and total phosphorus in detritus (positive correlation).

TABLE 3

Correlations between densities of invertebrate groups and the canonical variable, and correlations between water abiotic factors and chemical compounds on detritus of Eichhornia azurea and the canonical variable $W_{1}$ for the dry (D) and rainy $(R)$ periods.

\begin{tabular}{|c|c|c|c|c|c|}
\hline \multirow{2}{*}{$\begin{array}{l}\text { Invertebrate } \\
\text { groups }\end{array}$} & \multicolumn{2}{|c|}{ V1 } & \multirow{2}{*}{$\begin{array}{l}\text { Water abiotic factors and } \\
\text { compounds of detritus }\end{array}$} & \multicolumn{2}{|c|}{ W1 } \\
\hline & D & $\mathbf{R}$ & & D & $\mathbf{R}$ \\
\hline Ephemeroptera & $0.8375^{(1)}$ & -0.1739 & $\mathrm{~K}$ & -0.3219 & -0.1056 \\
\hline Chironomidae & $0.8464^{(1)}$ & $-0.6440^{(1)}$ & Temperature & $0.9278^{(1)}$ & $0.5912^{(1)}$ \\
\hline Copepoda & $0.8748^{(1)}$ & $-0.7244^{(1)}$ & Conductivity & $0.7408^{(1)}$ & 0.4170 \\
\hline Cladocera & -0.1339 & -0.3278 & Transparency & $-0.8124^{(1)}$ & $0.6110^{(1)}$ \\
\hline Oligochaeta & $0.5337^{(1)}$ & -0.1360 & Total $\mathrm{P}$ in detritus & -0.2491 & -0.5691 \\
\hline Ostracoda & $0.6109^{(1)}$ & $-0.7324^{(1)}$ & Total $\mathrm{N}$ in detritus & $0.7095^{(1)}$ & $-0.7322^{(1)}$ \\
\hline Gastropoda & $0.7802^{(1)}$ & -0.1275 & Polyphenols & $-0.7522^{(1)}$ & $0.5286^{(1)}$ \\
\hline Others $^{(2)}$ & $0.8838^{(1)}$ & -0.4205 & & & \\
\hline
\end{tabular}

${ }^{(1)}$ Correlations with $\mathrm{r}$ valores $>0.5$ were considered as significant.

${ }^{(2)}$ Others: Coleoptera, Odonata, Hemiptera, Ceratopogonidae, Culicidae, Nematoda, Hirudinea, Hydracarina, Collembola, Bivalvia, Trichoptera.

A significant association does not mean a cause-effect relationship. Roland et al. (1990) obtained for Eichhornia azurea a k value lower than the decomposition rates in Camargo Lake. In a experiment with Echinochloa polystachya in the same site, Pompêo \& Henry (1998) found a fast loss of biomass of leaf blades and the estimated time to decompose $50 \%$ of initial dry weight was of 29 days. The most important factors explaining the variability of different $\mathrm{k}$ values are 
the modifications on content, structure and configuration of plant skeleton compounds, which is typical of each habitat as they interact in a different way with microorganisms that had a significant role in the decomposition (Bastardo \& Rivera, 1986).

The alterations of the chemical composition of detritus during the decomposition had an important ecological significance. One of the modifications is an increase in nitrogen concentrations, as observed for some macrophytes (Esteves \& Barbieri, 1983; Poi de Neiff \& Neiff, 1988; Nogueira, 1989; Kuehn \& Suberkropp, 1998). According to Suren \& Lake (1989), the colonization of pioneer organisms as bacteria and fungus and later of periphytic algae, produces an evident increase in nitrogen and protein during the decomposition, what enriches the detritus nutritional quality and makes them more attractive for invertebrates. At the end of the experiment in Camargo Lake, an increase in nitrogen percentages was observed. But, an initial decrease was recorded in the first 14 days and it was due to detritus lixiviation. However, Roland et al. (1990) and Pagioro \& Thomaz (1998), both studying the Eichhornia azurea decomposition, observed a reduction on nitrogen concentrations at the end of the experiments.

Phosphorus can also be quickly released if the plant membrane permeability is changed (Rogers \& Bruyn, 1988), for instance when the plant is previously dried, as was the case for Camargo Lake. In the dry period, a positive correlation was found between phosphorus in detritus and decomposition rate of Eichhornia azurea. Pompêo \& Henry (1998) observed a decrease in phosphorus in remaining biomass of Echinochloa polystachya after the $7^{\text {th }}$ day of incubation in the same site. Esteves \& Barbieri (1983) and Roland et al. (1990) have also reported a reduction in phosphorus concentrations during the first days of decomposition.

According to Anderson (1973), the use of biomass of aquatic macrophytes for food, by grazers as well as by detritivorous organisms, is strongly influenced by polyphenol concentrations in plants. Esteves (1981), examining the content in 11 aquatic macrophyte species, found the highest polyphenol concentration in Eichhornia azurea. Nogueira (1989) observed that the values ranged from 16.3 to 41.8 UDO.g.DW ${ }^{-1}$ for this species. In Camargo Lake, the values of polyphenols in Eichhornia azurea presented, in the beginning of experiments, the same magnitude (23.3 and 33.2 UDO.g.DW ${ }^{-1}$ in the dry and rainy seasons, respectively). Esteves (1981) also showed that the mean value of organic matter in Eichhornia azurea of some reservoirs is 88.2\%; our data presented similar amounts. Da Silva et al. (1994), in a study of chemical composition of different macrophyte species of Lake Recreio (Mato Grosso), reported that, concerning organic matter and protein, Eichhornia azurea presented higher values than Eichhornia crassipes.

According to Trivinho-Strixino \& Strixino (1995), the live aquatic macrophytes are not a good food resource for the majority of macroinvertebrate species because they present uneasy digestion. During decomposition, bacteria and fungus produced an increase in nitrogen and protein, and the detritus became attractive as food source of the invertebrates. In Camargo Lake, the highest invertebrate densities were observed from the $14^{\text {th }}$ day of incubation, when a decrease in polyphenol content and an increase on nitrogen in remaining detritus of Eichhornia azurea were observed. The fast and high loss rates of polyphenol in Eichhornia azurea had an ecological importance, since these compounds cause a reduction in protein digestibility and palatability for the detritivorous chain (Heath \& Arnold, 1966). According to correlation analysis, the polyphenol contents and the total nitrogen percentages in the remaining biomass were correlated negatively and positively with the organisms (Ephemeroptera, Chironomidae, Copepoda, Oligochaeta, Ostracoda, Gastropoda and others) living in Eichhornia azurea in the dry period. But, in the rainy season, only some groups (Chironomidae, Copepoda, Ostracoda) presented a negative correlation with polyphenol concentrations.

The invertebrate density presents an inverse relationship with the remaining biomass of macrophyte during the decomposition (Bruquetas de Zozaya \& Neiff, 1991). In Camargo Lake, the decomposition rate of Eichhornia azurea was quicker during the rainy than the dry season, but the invertebrate density was lower. This was probably due to the influence of water circulation in the lake in the rainy season, in function of the connectivity with Paranapanema River.

Nessimian \& Lima (1997) observed that during the decomposition of Eleocharis sellowiana, Cladocera, Copepoda and Oligochaeta were the most representative groups of colonizers. In this study, the first three dominated in the dry period 
while Oligochaeta and Chironomidae were very abundant in the rainy season.

The majority of the species belongs to the collector group, specially in the rainy period, when the decomposition rate was higher. The dominance of collector invertebrates is probably due to the high amount of particulate matter and it is an index of prevalence of a detritivorous food chain in the macrophytes (Trivinho-Strixino et al., 1998). The great number of filter feeders in detritus of Eichhornia azurea in the first days of the experiment in the rainy season can be linked to the decomposition velocity, since there is a great food availability. According to Esteves \& Barbieri (1983), in the first days of decomposition, most of the material is released in a soluble way. According to Elmoor-Loureiro (1997), Chydoridae (Cladocera) are scrapper organisms on submerged plants. This can explain the high relative abundance in the first days of the experiment in the dry season. Predators occurred in great number when the remaining biomass of the macrophyte was very low. In the Eichhornia azurea, the highest relative density of shredders was found in the $7^{\text {th }}$ day of dry period, although in the rainy season no significant modifications were observed in its abundance along the experiment. According to Cummins et al. (1989), the shredders appear when microorganisms produce structural and biochemical alterations in plant tissues that are changed to a palatable nutritional status. Several causes can explain the association between invertebrates and macrophytes. In Eichhornia azurea, all the functional groups of organisms were observed in different proportions along the decomposition of the plant. Probably, it is due to the multiple functions of this substrate, that include refuge and food.

Acknowledgments — This research was supported by FAPESP (Thematic Project - Proc. 97/04999-8). N. de L. Stripari received a scholarship grant from FAPESP (Proc. 96/11943-6) and also a technical resource (Proc. 97/4147/1). Hamilton A. Rodrigues had an intense participation in field and laboratory works. Mrs. Célia Guimarães carried out the English revision of the manuscript.

\section{REFERENCES}

ANDERSON, J. M., 1976, An ignition method for the determination of total phosphorus in lake sediments. Water Res., 10: 329-331.

ANDERSON, J. M., 1973, The breakdown and decomposition of sweet chesnut (Castanea sativa Mill.) e beech (Fagus sylvatica L.) leaf litter in two deciduous woodland soils.
II. Changes in the carbon, hydrogen and polyphenol context. Oecologia, 12: 275-288.

ASSIS, C. V. \& COSTA, J. M., 1994, Seis novas larvas do gênero Micrathyria Kirby e notas sobre a distribuição no Brasil (Odonata, Libellulidae). Rev. Bras. Zool., 11: 195199.

BASTARDO, H. \& RIVERA, C. J., 1986, Colonización y sucesión microbiana durante la decomposición de gramineas tropicales. Acta Biol. Venez., 12: 66-71.

BOYD, C. E., 1970, Production, mineral accumulation and pigment concentrations in Typha latifolia and Scirpus americanus. Ecology, 51: 285-290.

BRUQUETAS de ZOZAYA, I. Y. \& NEIFF, J. J., 1991, Decomposition and colonization by invertebrates of Typha latifolia L. litter in chaco cattai swamp (Argentina). Aquat. Bot., 40: 185-193.

CUMMINS, K. W., WILZBACH, M. A., GATES, D. M., PERRY, J. B. \& TALIAFERRO, W. B., 1989, Shredders and riparian vegetation. Biosciences, 39: 24-30.

DA SILVA, C. J., NOGUEIRA, F. \& ESTEVES, F. A., 1994, Composição química das principais espécies de macrófitas aquáticas do lago Recreio Pantanal matogrossense (MT). Rev. Bras. Biol., 54: 617-622.

ELMOOR-LOUREIRO, L. M. A., 1997, Manual de identificação de Cladóceros límnicos do Brasil. Editora Universa, Brasília, 156p.

EPLER, J. H., 1992, Identification manual for the larval Chironomidae (Diptera) of Florida. Dpt. Environ. Reg., Orlando, 308p.

ESTEVES, F. A., 1981, Valor nutritivo da biomassa de algumas espécies de macrófitas aquáticas tropicais. In: Reunião sobre Ecologia e Proteção de Águas Continentais. São Carlos, Anais, pp. 229-244.

ESTEVES, F. A. \& BARBIEIRI, R., 1983, Dry weight and chemical changes during decomposition of tropical macrophytes in Lobo Reservoir. Aquat. Bot., 16: 285-295.

GADELHA, C. L. M., WATANABE, T. \& PASSERAT-DESILANS, A. M., 1990, Liberação de nutrientes inorgânicos durante o processo de decomposição de Ludwigia natans (S11) (Dicotyledoneae: Onagraceae) e de Salvinia auriculata (Aubl.) (Pteridophyta: Salviniaceae). Acta Limnol. Bras., 3: 633-652.

GODSHALK, G. L. \& WETZEL, R. G., 1978, Decomposition of aquatic angiospermus II. Particulate components. Aquat. Bot., 5: 301-327.

GOlterman, H. L., CLYMO, R. S. \& OHNSTAD, M. A. M., 1978, Methods for physical and chemical analysis of freshwaters. $2^{\text {nd }}$ ed., Oxford, IBP, Handbook, n. 8.

HEATH, G. W. \& ARNOLD, M., 1966, Studies in leaf-litter breakdown II. Breakdown rate of "sun" and "shade" leaves. Pedobiologia, 6: 238-243.

JUNK, W. J., BAYLEY, P. B. \& SPARKS, R. E., 1989, The flood pulse concept in river floodplain systems. Can. Spec. Fish. Aquatic. Sci., 106: 110-127.

KAUSHIK, N. K. \& HYNES, H. B. N., 1971, The fate of dead leaves that fall into streams. Arch. Hydrobiol., 68: 465-515. 
KING, H. C. \& HEATH, G. W., 1967, The chemical analysis of small samples of leaf material and the relationship between the disappearance and composition of leaves. Pedobiologia, 7: 192-197.

KUEHN, K. A. \& SUBERKROPP, K., 1998, Decomposition of standing litter of the freshwater emergent macrophyte Juncus effusus. Freshwater Biol., 40: 717-727.

LOPRETTO, E. C. \& TELL, G., 1995, Ecosistemas de águas continentales. Ediciones Sur, La Plata, T.3.

MANLY, B. F. J., 1994, Multivariate statistical methods. Chapman \& Hall, London, 215p.

MATSUMURA-TUNDISI, T., 1986, Latitudinal distribution of Calanoida copepods in freshwater aquatic systems of Brazil. Rev. Bras. Biol., 46: 527-553.

MERRITT, R. \& CUMMINS, K. W., 1996, An introduction to the aquatic insects of North America. $3^{\text {th }}$ ed. Kendal/ Hunt, Duduque, 862p.

MOSCHINI-CARLOS, V., POMPÊO, M. L. M. \& HENRY, R., 1998, Caracterização limnológica de uma bacia marginal ao Rio Paranapanema (zona de desembocadura na Represa de Jurumirim, SP). Acta Limnol. Bras., 10: 119.

NESSIMIAN, L. \& LIMA, I. H. A. G., 1997, Colonização de três espécies de macrófitas por macroinvertebrados aquáticos em um brejo no litoral de estado do Rio de Janeiro. Acta Limnol. Bras., 9: 149-163.

NOGUEIRA, F., 1989, Importância das macrófitas aquáticas Eichhornia azurea Kunth e Scirpus cubensis Poepp \& Kunth na ciclagem de nutrientes e nas principais características limnológicas da Lagoa do Infernão (SP). Dissertação de Mestrado, UFSCar, 147p.

PAGIORO, T. A. \& THOMAZ, S. M., 1998, Loss of weight and concentration of carbon nitrogen and phosphorus during decomposition of Eichhornia azurea in the floodplain of the upper Paraná river, Brazil. Rev. Bras. Biol., 58: 603-608.

PAGIORO, T. A. \& THOMAZ, S. M., 1999, Decomposition of Eichhornia azurea from limnologically different environments of the Upper Paraná River floodplain. Hydrobiologia, 411: 45-51.

PENNAK, R. W., 1991, Freshwater Invertebrates of the United States. $3^{\text {th }}$ ed., John Wiley \& Sons, New York, 628p.

POI DE NEIFF, A. \& NEIFF, J. J., 1988, Decomposition of Eichhornia crassipes Solms in ponds of Paraná river valley and colonization by invertebrates. Trop. Ecol., 2: 79-85.

POMPÊO, M. L. M., 1996, Ecologia de Echinochloa polystachya (H. B. K.) Hitchcock na Represa de Jurumirim na zona de desembocadura do Rio Paranapanema-SP. Tese de Doutorado, São Carlos, 150p.
POMPÊO, M. L. M. \& HENRY, R., 1998, Decomposition of macrophyte Echinochloa polystachya (H. B. K.) Hitchcock in a Brazilian Reservoir (Paranapanema River mouth zone). Verh. Int. Verein. Limnol., 26: 1871-1875.

RAMCHARAN, V. \& PATERSON, C. G., 1978, A partial analysis of ecological segregation in the Chironomid community of a bog lake. Hydrobiologia, 58: 129-135.

REID, J. W., 1982, Chave de identificação e lista de referências bibliográficas para as espécies continentais sulamericanas de vida livre da ordem Cyclopoida (Crustacea, Copepoda). Bolm. Zool. USP, 9: 17-143.

ROGERS, K. H. \& BRUYN, J., 1988, Decomposition of Paspalum distichum L., methodology in seasonally inundated systems. Verh. Int. Verein. Limnol., 23: 1945-1948.

ROLAND, F., ESTEVES, F. A. \& SANTOS, J. E., 1990, Decomposição da macrófita aquática Eichhornia azurea (Kunth), com ênfase na colonização por bactérias epifíticas. Acta Limnol. Bras., 3: 653-673.

SOKAL, R. R. \& ROHLF, F. J., 1995, Biometry: the principles and practice of statistics in biological research. W. H. Freeman, New York, 887p.

SOSZKA, G. J., 1975, The invertebrates on submersed macrophytes in three Masurian lakes. Ekol. Pol., 23: 271-391.

SUREN, A. M. \& LAKE, P. L., 1989, Edibility of fresh and decomposing macrophytes to three species of freshwater invertebrate herbivores. Hydrobiologia, 178: 165-178.

TRIVINHO-STRIXINO, S. \& STRIXINO, G., 1995, Duas novas espécies de Nimbocera reiss (Díptera: Chironomidae) do estado de São Paulo, Brasil. Rev. Brasil. Entomol., 35: 173-178.

TRIVINHO-STRIXINO, S., STRIXINO, G., GESSNER, F. A. \& CORREIA, L., 1998, Macroinvertebrados associados a macrófitas aquáticas das lagoas marginais da estação de Jataí (Luiz Antônio, SP). In: Seminário Regional de Ecologia, 3., São Carlos, Anais, pp. 1189-1198.

TRIVINHO-STRIXINO, S. \& STRIXINO, G., 1995, Larvas de Chironomidae (Díptera) do Estado de São Paulo. Guia de identificação e diagnóstico dos gêneros. São Carlos, PPG-ERN, 229p.

VICENT, B., LAFONTAINE, N. \& CARON, P., 1982, Facteurs influençant la structure des groupements de macroinvertébrés benthiques et phytophiles dans la zone littorale du Saint-Laurent (Québec). Hydrobiologia, 97: 67-73. 